\title{
Customer Loyalty of Traditional Market the Role of In-Store Logistics, Store Image and Satisfaction
}

\author{
Moh Farid Najib \\ Department of Business Administration \\ Bandung State Polytechnic \\ Bandung, Indonesia \\ mohfaridnajib@polban.ac.id
}

\begin{abstract}
The main purpose of this study was to analyse the effect of in-store logistics on store image, customer satisfaction, and loyalty in the context of the Indonesian traditional market. The proposed model also points to examine the relationship between in-store logistics, stock images, satisfaction, and commitment. A survey was conducted on $\mathbf{4 0 0}$ shoppers in $\mathbf{1 6}$ traditional markets around West Java, Indonesia. The methodology used consists of two stages. The first step was to check the construct validity through Convergent Validity (CV), Average Variance Extracted (AVE), Construct Reliability (CR), and Discriminant Validity (DC). Secondly, a structural equation model procedure was used to test the proposed research model. The results of this research indicate that in-store logistics positively influences store image and Loyalty. Nevertheless, it negatively affects satisfaction. Furthermore, store image positively influences satisfaction, but it negatively influences loyalty. Similarly, satisfaction also positively influences loyalty. However, it negatively affects satisfaction. Furthermore, store image positively influences satisfaction, but it negatively influences loyalty. Similarly, satisfaction also positively influences loyalty. Store image and satisfaction are mediating the relationship between in-store logistics and loyalty
\end{abstract} loyalty

Keywords-in-store logistics, store image, satisfaction,

\section{INTRODUCTION}

The availability of products relates to a good distribution system which will guarantee in-store logistics because there will be no transaction if the product is not available. Thus, in-store logistics is related to the availability of products in the market, both traditional and modern markets [1]. However, the sales growth generated from the distribution among traditional markets, supermarkets/hypermarkets and mini markets shows a decline in $2002 \quad(74.8 \%$ traditional market, supermarket/hypermarket $20.2 \%$, and mini market 4.0\%), 2005 (traditional market $67.6 \%$, supermarket/hypermarket $22.2 \%$, and mini market $10.2 \%$ ) and 2011 (traditional market 55.8\%, supermarket/hypermarket $21.8 \%$, and mini market $22.4 \%$ ) [2]. It indicates that the distribution of products by traditional markets is decreasing compared to supermarkets/hypermarkets and mini markets do. This slowness is caused by several factors, such as; lack of buyers, increasing competition, high prices of suppliers, and increasingly difficult to get products [3]. On the other hand, product availability is highly dependent on how the country can produce the needed products, which means that when a country can produce everything, its centralization policies can override competitors [4]. Thus obstacles in every trade, especially with the import substitution policy, ensure that competition is not a major factor, because the number of products demanded is greater than supply, so unnecessary sales and segmentation are not considered. This condition is caused by the quality of traditional market services compared to those of modern markets' in almost all retail service quality dimensions which indicate that the modern markets are much better than traditional markets' [5].

The traders in traditional markets mostly still claim that prices, products, places, and promotions as a source of their competitive advantage, thus they ignore the potential of in-store logistics for creating customer value [6]. Whereas achieving competitive advantage needs to improve the service experience of retail [7]. The quality of logistics services is known as a major factor, when customers make decisions about where they have to buy or return to their retailers [8], [9]. Besides, the functions of availability, delivery conditions, and timeliness for creating customer value are promoted as a criterion for evaluating operations of logistics [10], [11]. The interesting opportunities are presented with excellence in logistical operations [12]. In-store logistics operations consist of handling order management and processing of in-store merchandise which both focus on process flow in store-based retail outlets [1]. 
In this paper, we concentrate on how the logistic operations can occur inside the store and evaluate the relationship between perceptions of in-store logistics, store image, and its impact on customer satisfaction and loyalty. Based on the explanation given, this study aims to evaluate the relationship between in-store logistics on store image and its impact on customer satisfaction and customer loyalty within the Indonesian traditional market context.

\section{LITERATURE REVIEW}

\section{A. In-Store Logistics}

In-store logistics relates to the operating system for managing inventory flows from the store to the point of sale through the warehouse [13]. In-store logistics emphasize all flow processes in store-based retail outlets. The outlet is the location of the transaction/exchange for the product being traded as well as the payment. In-store logistics operations include handling, ordering, arranging, and processing of the merchandise in the store [14]. Therefore, product availability plays a major role in retail activities, when there is no product availability then there will be no purchase intention [1]. There are five main categories on the operational of logistical activities within a store, namely: forward and backward logistics, store activities, inventory management, multichannel retail activities, management of data, and in-store master planning[13]. However, studies that focus on logistics operations in-store are relatively few [15], especially from a customer perspective.

\section{B. Store Image}

Store image as the "personality" of a store in the minds of customers [16]. Store image which includes corporate or store image serves as a major driver of customer satisfaction [17]. Several types of research have been tested to classify the basic elements or dimensions that influence the store's image. The store image reproduces how the customer experience, and then form the cumulative experience into three areas of the store image constructs namely merchandise, layout, and personnel [16]. The complexity of consumers perceptions of stores with different characteristics is an evaluation of the appropriate elements of service experience. This condition is a unity of customer confidence about the attractiveness of the store. Therefore, customer perceptions of the store image will differ in other countries in terms of geographical regions, market areas, and store design and it is considered relative to competition [16], [18].

\section{Satisfaction}

Customer satisfaction is the desired target for business because satisfied customers will tend to buy more, make repeat buying, and spread positive information by word of mouth. Satisfaction is the result of a comparison between experience with previous expectations [19]. Regarding customer visits to the store, it is not only based on previous expectations, but also prior customer experience and mouth-to-mouth information from other customers. In the retail business, measuring customer satisfaction can be done by comparing with other retailers, shopping experience, price, quality of service, or product offered [20].

The first dimension of customer satisfaction is store service-scape. Many arguments suggest that customer satisfaction will increase when the customer experience of retail store services is related to the ease of finding the product sought by the customer. So that when the order of goods in the store shows proper and presents sufficient signs, then the customer will become satisfied [21], [22]. Another dimension is the product/merchandise available in the store [23], and the involvement of store personnel in interacting with customers [24]. Personal interaction with service providers is quite important for customer satisfaction [25], [26], as interactions with service providers demonstrated by the quality of personnel and customer convenience.

\section{Customer Loyalty}

Customer loyalty is the primary objective of relationship marketing and is often equated with the relationship marketing concept[27]. Customer loyalty is not only behavior, but it is also a function of basic psychological factors[28]. However, there is no general consent in measuring customer loyalty in the marketing literature [29]. Measuring customer loyalty it is necessary to include attitudes and behavioral dimensions [30]. There are four stages to create customer loyalty, namely customer trust, customer knowledge, confidence and benefits, confidence in quality [31].

\section{E. In-Store Logistics, Store Image, Customer Satisfaction, and Customer Loyalty}

The main goal of in-store logistics management is to increase sales and profits by creating customer value through the power of merchandising and psychology [32]. The objectives of integrated logistics, both internal and external of the supply chain company, are to increase customer value [33]. Therefore, the stores can be separated between what they offer through simplifying the shopping experience by customers and how they create customer satisfaction through more convenient services [34] because retailer logistics operations and in-store logistics can determine partly how the interaction experienced by customers [12]; as well as customers can make better purchasing decisions if supported by sufficient information [10]. Through the creation of value for them, the customers are generally very aware of the information provided in the store, and how the store handles customer complaints, shopping convenience, and other factors of the customer shopping experience can have a disproportionate influence on the customer perception about the store [35]. Therefore, in-store logistics that meets customer expectations will form store images based on customer 
satisfaction and ultimately create customer loyalty. Furthermore, customer loyalty forms from customer satisfaction in the Indonesian traditional markets [36]. Thus the possible hypothesis are;

$\mathrm{H}_{1}$ : Customer perception of in-store logistics performance is directly and positively associated with store image.

$\mathrm{H}_{2}$ : Customer perception of in-store logistics performance is directly and positively associated with customer satisfaction

$\mathrm{H}_{3}$ : Customer perception of in-store logistics performance is directly and positively associated with customer loyalty
$\mathrm{H}_{4}$ : Store image is directly and positively associated with customer satisfaction

$\mathrm{H}_{5}$ : Store image is directly and positively associated with customer loyalty

$\mathrm{H}_{6:}$ Customer satisfaction is directly and positively associated with customer loyalty.

\section{F. Conceptual models}

Figure 1 provides a visual depiction of the conceptual model that encapsulates the abovementioned constructs and hypotheses. This will be subject to empirical testing.

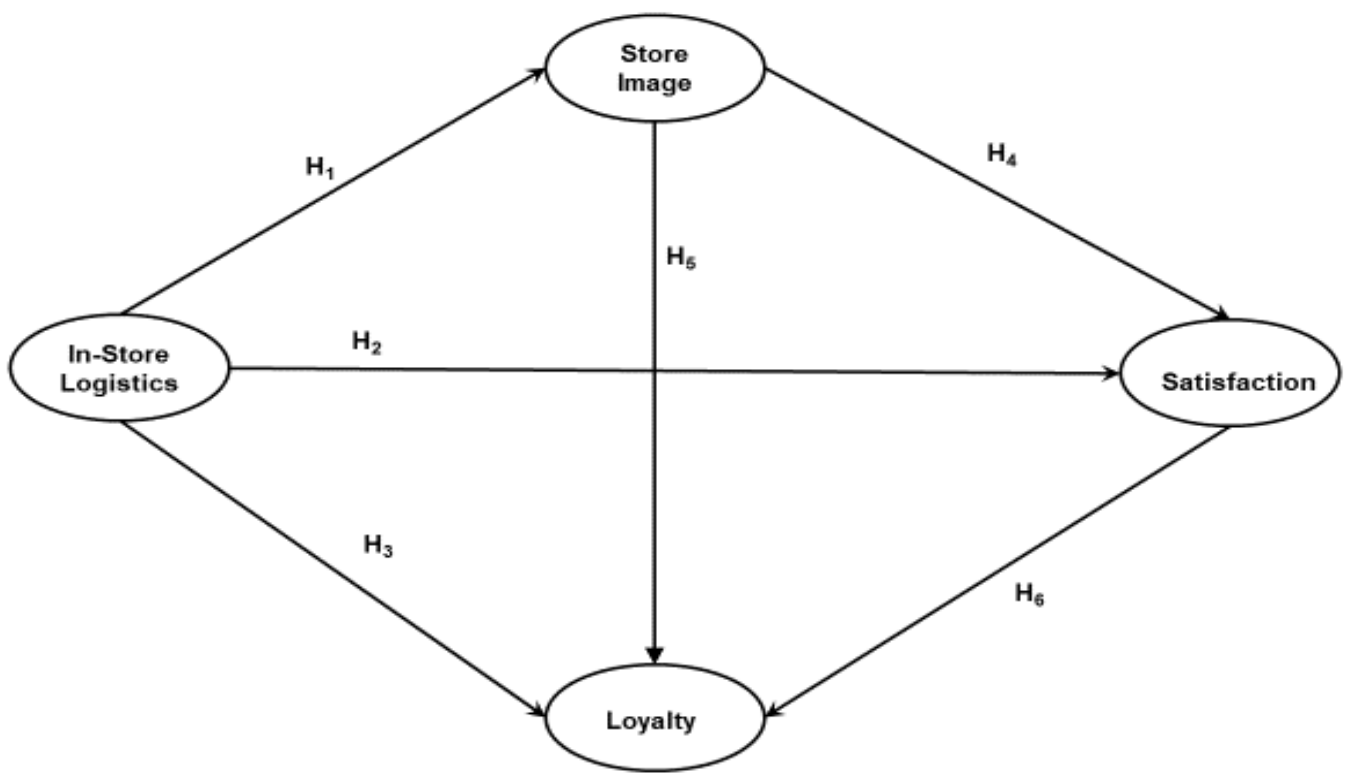

Fig. 1. Research Model

\section{METHODOLOGY}

The general purpose of this research is to analyze the influence of in-store logistics on customer loyalty both directly and indirectly through store image and customer satisfaction in the context of the Indonesian Traditional Market. In-store logistics is an important factor that guarantees the availability of products in the store. Following the research objectives, the type of research used is explanatory research. Verification research is used because this type of research is relational problems, the conceptual framework is logical thinking, alternative problem solving is a relational hypothesis. As hypothesis testing uses calculations of infertility statistics the explanatory survey method is used as the research method to reveal the clarity of relationships and influence among research variables.

The data collection was done with a time horizon which was one shot/cross-sectional because this research was conducted only once. The one-shot/crosssectional means that the data or information collected is the result of research conducted in a certain period [37]. The sample size is 400 respondents who shop from 16 different traditional markets places around West Java, Indonesia. Table 1 shows the profile of respondents in this study covering gender, age, income, occupation, and education. 
TABLE I. RESPONDENT'S PROFILE

\begin{tabular}{|c|c|c|c|c|c|}
\hline Descriptions & Freq & $\%$ & Descriptions & Freq & $\%$ \\
\hline \multicolumn{3}{|c|}{ Gender } & \multicolumn{3}{|c|}{ Occupation } \\
\hline Male & 107 & 27 & Government employees & 50 & 13 \\
\hline Female & 293 & 73 & Private employees & 42 & 11 \\
\hline Total & 400 & 100 & Trader & 82 & 21 \\
\hline \multicolumn{3}{|c|}{ Age } & Housewife & 153 & 38 \\
\hline Less than 20 years old & 33 & 8 & Student & 40 & 10 \\
\hline 20 to 30 years old & 122 & 31 & Enterpreneur & 20 & 5 \\
\hline 30 to 40 years old & 97 & 24 & Others & 13 & 3 \\
\hline 40 to 50 years old & 92 & 23 & Total & 400 & 100 \\
\hline 50 too old more & 56 & 14 & \multicolumn{3}{|c|}{ Education Level } \\
\hline Total & 400 & 100 & Primary school & 30 & 8 \\
\hline \multicolumn{3}{|c|}{ Income (IDR) } & Secondary school & 76 & 19 \\
\hline Less than 2.500 .000 & 220 & 55 & High school & 193 & 48 \\
\hline 2.500 .000 until 5.000 .000 & 144 & 36 & Diploma III & 46 & 12 \\
\hline 5.000 .000 until 7.500 .000 & 32 & 8 & Dimploma IV/Bachelor & 48 & 12 \\
\hline 7.500 .000 more & 4 & 1 & Magister & 5 & 1 \\
\hline Total & 400 & 1 & Doctor & 2 & 1 \\
\hline & Total & 400 & 100 \\
\hline
\end{tabular}

Development of the research instruments is carried out for the first construct, namely in-store logistics, which is a combination of research and concepts from previous studies [6], [13], [15]. The second construct, namely store image was developed from [6], [16], [18]. The third construct is customer satisfaction was developed from [38], [39]. Similarly, customer loyalty has also been used in many previous studies [38], [40], [41].

\section{RESULTS AND DISCUSSION}

\section{A. Reliability Analysis and Measurement Model}

A good questionnaire must be described through the level of stability, consistency, and homogeneity, therefore testing of research instruments needs to be done, besides that the questionnaire should be clear, easy to understand, comprehensive, consistent, unequivocal, and not causal, and should not cause unclear answer. The reliability test was used SPSS 23 (see Table 2). The results of reliability analysis showed that both dimensions and sub-dimensions showed the results of Cronbach's Alpha coefficient were greater than 0.7, which means that it was very reliable [42], [43]. Also, confirmatory factor analysis was used to test the structure of the construct factor, and to estimate the parameter model. This analysis also tests the multidimensionality of the theoretical constructs.

Confirmatory factor analysis, both of exogenous constructs (in-store logistics) are acceptable or has a goodness of fit with the CMIN $=2.498$. The absolute fit index of acceptable measurement model with RMSEA $=0.059$, with additional index and GFI $=$ $0.932, \mathrm{AGFI}=0.921, \mathrm{TLI}=0.950, \mathrm{NFI}=0.942, \mathrm{CFI}=$ $0.963, \mathrm{IFI}=0.963$, and RFI $=0.936$ [44]. Confirmatory factor analysis of endogenous constructs (store image, customer satisfaction and loyalty) are also acceptable (has a goodness of fit) with the results of store image are $\mathrm{CMIN}=2,783$, and the absolute fit index of acceptable measurement model at RMSEA $=0.076$, with additional indexes and GFI $=0.905$, AGFI $=$ $0.901, \mathrm{TLI}=0.946, \mathrm{NFI}=0.934, \mathrm{CFI}=0.943, \mathrm{IFI}=$ 0,943 , and RFI $=0.924$. The last confirmatory factor analysis of another endogenous constructs (customer satisfaction and loyalty) are acceptable (has a goodness of fit) with the results of customer satisfaction and loyalty are CMIN $=2.630$, and the absolute fit index of acceptable measurement model at RMSEA $=0.064$, with additional indexes and GFI $=0.921$, AGFI $=$ $0.906, \mathrm{TLI}=0.948, \mathrm{NFI}=0.524, \mathrm{CFI}=0.959, \mathrm{IFI}=$ 0.959 , and RFI $=0.938$.

TABLE II. THE RESULTS OF RELIABILITY ANALYSIS

\begin{tabular}{|l|c|c|c|c|c|}
\hline $\begin{array}{c}\text { Dimensions / } \\
\text { Sub-dimensions }\end{array}$ & Loading Factor & $\begin{array}{c}\text { Cronbach's } \\
\text { Alpha }\end{array}$ & $\begin{array}{c}\text { Average Variance } \\
\text { Extracted }\end{array}$ & $\begin{array}{c}\text { Construct } \\
\text { Reliability }\end{array}$ & Discriminant Validity \\
\hline In-Store Logistics & $\mathbf{0 , 9 3 3}$ & & & \\
\hline Stock & 0,867 & 0,850 & 0,742 & 0,915 & \\
\hline SS2 & 0,856 & & & & 0,862 \\
\hline SS1 & & 0,908 & 0,834 & 0,950 & \\
\hline Return & 0,880 & & & & 0,913 \\
\hline RT2 & 0,945 & & & & \\
\hline RT1 & & 0,908 & 0,709 & & \\
\hline Shopping Aid & 0,758 & & & & \\
\hline SC4 & 0,750 & & & & \\
\hline SC3 & 0,911 & & & & \\
\hline SC2 & 0,933 & & & & \\
\hline SC1 & & & & \\
\hline
\end{tabular}




\begin{tabular}{|c|c|c|c|c|c|}
\hline Product & & 0,780 & 0,675 & 0,876 & 0,822 \\
\hline PT2 & 0,929 & & & & \\
\hline PT1 & 0,698 & & & & \\
\hline Information & & 0,767 & 0,699 & 0,637 & 0,836 \\
\hline INF4 & 0,680 & & & & \\
\hline INF1 & 0,967 & & & & \\
\hline Store Image & & 0,937 & & & \\
\hline Merchandise & & 0,885 & 0,750 & 0,935 & 0,866 \\
\hline MC4 & 0,884 & & & & \\
\hline MC3 & 0,908 & & & & \\
\hline MC2 & 0,837 & & & & \\
\hline MC1 & 0,632 & & & & \\
\hline Layout & & 0,806 & 0,576 & 0,875 & 0,759 \\
\hline LY3 & 0,86 & & & & \\
\hline LY2 & 0,69 & & & & \\
\hline LY1 & 0,715 & & & & \\
\hline Personnel & & 0,900 & 0,697 & 0,944 & 0,835 \\
\hline PL4 & 0,829 & & & & \\
\hline PL3 & 0,845 & & & & \\
\hline PL2 & 0,888 & & & & \\
\hline PL1 & 0,773 & & & & \\
\hline Satisfaction & & 0,949 & 0,776 & 0,975 & 0,881 \\
\hline SF6 & 0,865 & & & & \\
\hline SF5 & 0,904 & & & & \\
\hline SF4 & 0,844 & & & & \\
\hline SF3 & 0,885 & & & & \\
\hline SF2 & 0,885 & & & & \\
\hline SF1 & 0,693 & & & & \\
\hline Loyalty & & 0,968 & 0,795 & 0,972 & 0,892 \\
\hline LOY5 & 0,902 & & & & \\
\hline LOY4 & 0,947 & & & & \\
\hline LOY3 & 0,955 & & & & \\
\hline LOY2 & 0,939 & & & & \\
\hline LOY1 & 0,897 & & & & \\
\hline
\end{tabular}

The result of construct validity as shown in table 2 indicates the convergent validity, the average variance extracted, construct reliability, and discriminant validity. The convergent validity is measured by the value of the loading factor and that the convergent validity is the indicator of the construct should converge or share a proportion of the variance. The result of the standardized output of the loading estimate as shown in Table 2 indicate that all of the loading factors already above 0.5 [44], [45]. This means that in general the loading factor statistically significant and the loading factor already above 0.50 .

In the confirmatory factor analysis, the average percentage of variance extracted (AVE) between items or a set of indicators of latent constructs is a summary of the convergent indicator. The construct validity meets the criteria AVE> 0.50 [45], this happens because the factor loading is above 0.70 which means this indicates that the convergences are good. The results showed that almost all AVE dimensions/subdimension of in-store logistics, store image, satisfaction, and loyalty are above 0.5 as shown in Table 2. The coefficient of the construct reliability should be more than 0.70 and that it's good reliability, while reliabilities $0.6-0.7$ can still be accepted [45]. The results of the construct reliability showed in Table 2 indicate that all of the dimensions / sub-dimension above 0.7 , while dimension / the sub-dimension construct reliability values below 0.7 are (information is 0.637), however, it's still accepted [45].

\section{B. Structural Equation Model}

The structural equation modeling combines both exogenous and endogenous latent variables or combines the relationship between exogenous with other endogenous variables. The confirmatory factor analysis conducted for measuring both the exogenous and endogenous latent variables has resulted in the overall model as shown in Figure 2. 


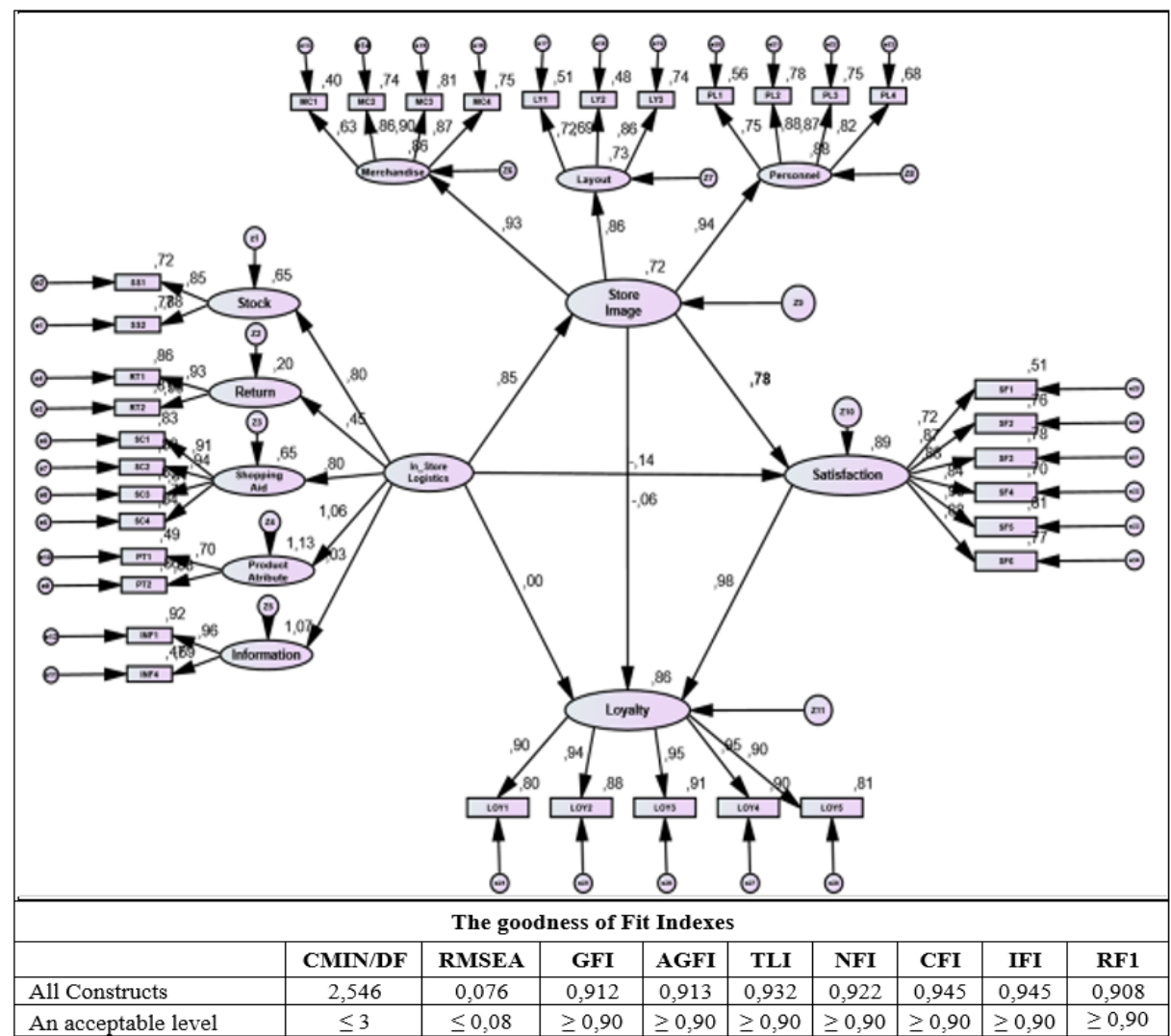

Fig. 2. Full Model

\section{Discussion and Conclusion}

The purpose of this research is to analyse the effect of in-store logistics on store image, customer satisfaction, and loyalty in the context of the Indonesian traditional market. Based on the results shown in Figure 3 and Table 3, the effect of these variables is clear: instore logistics, store image, customer satisfaction, and customer loyalty.

TABLE III. Hypothesis Testing RESUltsTABLE

\begin{tabular}{|l|l|l|l|c|r|r|r|r|}
\hline \multicolumn{3}{|c}{ Hypothesis } & Standardize (Estimated) & SE & CR & P-Value & Result \\
\hline $\mathrm{H}_{1}$ & In-Store Logistics & $\rightarrow$ & Store Image &, 803 &, 052 & 12,88 & $* * *$ & Accepted \\
\hline $\mathrm{H}_{2}$ & In-Store Logistics & $\rightarrow$ & Satisfaction &,- 148 &, 069 & $-2,160$ &, 031 & Rejected \\
\hline $\mathrm{H}_{3}$ & In-Store Logistics & $\rightarrow$ & Loyalty &, 000 &, 078 &,- 005 &, 996 & Rejected \\
\hline $\mathrm{H}_{4}$ & Store Image & $\rightarrow$ & Satisfaction & 1,187 &, 111 & 10,698 & $* * *$ & Accepted \\
\hline $\mathrm{H}_{5}$ & Store Image & $\rightarrow$ & Loyalty &,- 086 &, 215 &,- 401 &, 688 & Rejected \\
\hline $\mathrm{H}_{6}$ & Satisfaction & $\rightarrow$ & Loyalty & 1,227 &, 162 & 7,581 & $* * *$ & Accepted \\
\hline
\end{tabular}

The SEM results as shown in Table 2, mention that $\mathrm{H} 1$ (customer perception in-store logistics performance is directly and positively associated with store image) and show that a critical value (CR) of 12,881 for the association of in-store logistics to store images, and the $\mathrm{P}$-value (probability) are signification with $* * *$ or significant by default. It means that the regression weight for store image predicted in-store logistics is significantly different from zero at the 0.05 (two-tailed) level, thus Ho is rejected and $\mathrm{Ha}$ is accepted.
Based on these results it can be concluded that instore logistics has a significant impact on store image. The results of the study are in line with the previous study [6], [24], [35] which states that shopping convenience and facility aspects build customer perceptions of stores. Thus, the increase of design, planning, and controlling in-store logistics operations can improve customer perceptions of the store, this condition supports the estimation [14]. In-store logistics directly contributes $85 \%$ to store the image. It shows that the perception of shoppers about store image of the 
traditional market is dependent on how the quality of in-store logistics. The result of this research shows the positive effect of in-store logistics on store image, this implies that a better in-store logistics of traditional markets regarding stock, return, shopping aid, product attributes, and information can increase store image of the traditional market.

However, the dimensions of product return and information are the sub-variables that have the lowest contribution to the image of the traditional market. This condition occurs because traditional markets are perceived as temporary with slums, expose a lot of garbage, dirt, and narrow corridors [3]. Product availability that is reflected in the in-store logistics operations that guarantee the availability and ease of getting the desired product will increase store image, this result is in line with the previews findings [16], [17], [35].

$\mathrm{H} 2$ (customer perception in-store logistics performance directly and positively associated with customer satisfaction). The result shows that the critical value $(\mathrm{CR})-2.160$ for the influence of in-store logistics on customer satisfaction, and P-value (probability) signification with 0.031 which means by default is notsignificant. In other words, the regression weight for customer satisfaction is predicted by the in-store logistics significantly; it was decided to accept Ha and reject Ho. It can be concluded that in-store logistics does not affect the customer satisfaction of traditional market shoppers in West Java, Indonesia; the absence of a positive influence on the in-store logistics on customer satisfaction. Thus, the findings of this study are different from the previous research on research at supermarkets [6]. This is because, logistics operations in retail and in-store logistics businesses occupy a very large portion of the customer interaction experience in interacting [12].

H3 (customer perception in-store logistics performance is directly and positively associated with customer loyalty) reveals a critical value (CR) -0.005 on the effect of customer satisfaction on customer loyalty, and the P-value (probability) signification at 0.996 , by default, is not significant. It means the regression weight for customer loyalty is predicted by in-store logistics significantly; it was decided to accept $\mathrm{Ha}$ and reject Ho. Based on these results it can be concluded that in-store logistics does not affect the customer loyalty of the traditional market shoppers in West Java, Indonesia. The findings reveal no positive influence of the in-store logistics on customer loyalty. This is because customer loyalty is built from satisfied customers, while in traditional markets, customer satisfaction is more influenced by store image.

H4 (store image is directly and positively associated with customer satisfaction) displays a critical value (CR) 10.698 for the influence of store image on customer satisfaction, at the P-value (probability) signification with $* * *$ which means by default is significant. This means the regression value for customer satisfaction is projected from the store image. Customer satisfaction is different from zero at the 0.05 (two-tailed) level, accordingly, Ho is accepted and Ha is rejected. The results conclude that the store image influence on customer satisfaction of the traditional market shoppers in West Java, Indonesia. Store image directly contributes $78 \%$ to customer satisfaction. It implies that market shoppers are satisfied with the store image of traditional markets. The influence of store image on customer satisfaction supports the previews opinion [6], [17]. Furthermore, the good store image will make customers more comfortable and satisfied [34],

H5 (store image is directly and positively associated with customer loyalty) provides a critical value (CR) 0.401 in the influence of store image on customer loyalty, at the P-value (probability) signification with 0.688 which is not significant. It indicates that the regression value for customer loyalty was projected by the store image so that $\mathrm{Ho}$ is rejected and $\mathrm{Ha}$ is accepted. Therefore it can be concluded that store image is not directly and positively associated with customer loyalty of the traditional market shopper in West Java, Indonesia. The result of this research reveals that store image has no direct effect on loyalty.

H6 (customer satisfaction is directly and positively associated with customer loyalty) disclose a critical value (CR) 7.581 on the influence of customer satisfaction on customer loyalty, at the $\mathrm{P}$-value (probability) signification with $* * *$ indicating significant by default. It means the regression weight for customer loyalty is projected. Customer satisfaction is different from zero at 0.05 (two-tailed) level, as a result, Ho is rejected and $\mathrm{Ha}$ is accepted. Thus it can be concluded that the customer satisfaction of the traditional market in West Java, Indonesia directly provides $98 \%$ to customer loyalty. It implies that the shoppers of the traditional market have loyalty. The results of this study prove that customer satisfaction is directly and positively associated with customer loyalty. These findings are in line with the previous studies [5], [6].

\section{FURTHER RESEARCH}

The data collected on this study is mostly explorative and carried out in the province of West Java over 16 traditional markets by the analysis unit of the traditional market shopper. Further research on the perception of logistic construction through harmony with suppliers, dynamic capabilities, and the ability to innovate from traders would be interesting to provide a more comprehensive review of the traditional market. Besides that, retail logistics construction needs to be developed further, especially the construction of retail logistics in traditional markets, modern markets, and eretailing. 


\section{ACKNOWLEDGMENT}

This research supported by Bandung State Polytechnic, Indonesia, Research Grant No. 140.56/PL1.R7/PG.00.03/2020.

\section{REFERENCES}

[1] H. Kotzab and C. Teller, "Development and empirical test of a grocery retail instore logistics model," British Food Journal. 2005, doi: 10.1108/00070700510610995.

[2] Indonesia Retail Report., Including 5-year Industry Forecasts by BMI. London, UK: Business Monitor International, 2013.

[3] D. Suryadarma, A. Poesoro, S. Budiyati, Akhmadi, and M. Rosfadhila, Dampak Supermarket terhadap Pasar dan Pedagang Ritel Tradisional di Daerah Perkotaan di Indonesia. 2007

[4] L. P. Dana, Asian Models of Entrepreneurship: From the Indian Union and the Kingdom of Nepal to the Japanese Archipelago: Context, Policy \& Practice. World Scientific, 2007.

[5] M. F. Najib and A. Sosianika, "Retail service quality scale in the context of Indonesian traditional market," Int. J. Bus. Glob. vol. 21, no. 1, 2018, doi: 10.1504/IJBG.2018.094093.

[6] O. Bouzaabia, A. C. r. Van Riel, and J. Semeijn, "Managing in-store logistics: A fresh perspective on retail service," J. Serv. Manag., 2013, doi: 10.1108/09564231311323926.

[7] S. L. Vargo and R. F. Lusch, "Service-dominant logic: Continuing the evolution," J. Acad. Mark. Sci., 2008, doi: 10.1007/s11747-007-0069-6.

[8] C. C. Bienstock, J. T. Mentzer, and M. M. Bird, "Measuring physical distribution service quality," J. Acad. Mark. Sci. 1997, doi: 10.1007/BF02894507.

[9] M. Rafiq and H. S. Jaafar, "MEASURING CUSTOMERS' PERCEPTIONS OF LOGISTICS SERVICE QUALITY OF 3PL SERVICE PROVIDERS," J. Bus. Logist., 2007, doi: 10.1002/j.2158-1592.2007.tb00062.x.

[10] J. Mentzer, D. Flint, and J. Kent, "Developing a logistics service quality scale," J. Bus. Logist., 1999.

[11] M. Zineldin, "Total relationship and logistics management," Int. J. Phys. Distrib. Logist. Manag., 2004, doi: 10.1108/09600030410533592.

[12] A. Yazdanparast, I. Manuj, and S. M. Swartz, "Co-creating logistics value: A service-dominant logic perspective," Int. J. Logist. Manag., 2010, doi: 10.1108/09574091011089808.

[13] M. Bernard, R. Kingsford, and O. Fredrick, "EFFECT OF INSTORE LOGISTICS OPERATIONS PRACTICES ON CUSTOMER SATISFACTION IN SUPERMARKETS IN MOMBASA COUNTY, KENYA," Int. J. Sci. Arts Commer., vol. 1 , no. 8, pp. $30-44,2016$

[14] A. C. Samli, T. L. Pohlen, and L. Jacobs, "Developments in Retail Logistics," J. Mark. Channels, 2005, doi: 10.1300/j049v13n02_05.

[15] A. C. Mckinnon, D. Mendes, and M. Nababteh, "In-store logistics: an analysis of on-shelf availability and stockout responses for three product groups," Int. J. Logist. Res. Appl., vol. 10, no. 3, pp. 251-268, 2007, doi $10.1080 / 13675560701478075$.

[16] S. Burt and A. Mavrommatis, "The international transfer of store brand image," Int. Rev. Retail. Distrib. Consum. Res. 2006, doi: 10.1080/09593960600844178.

[17] T. W. Andreassen and B. Lindestad, "Customer loyalty and complex services. The impact of corporate image on quality, customer satisfaction and loyalty for customers with varying degrees of service expertise," Int. J. Serv. Ind. Manag., 1998, doi: 10.1108/09564239810199923.

[18] P. Martineau, “The Personality of the Retail Store," Harv. Bus. Rev., 1958
[19] Oliver R. L. "A Cognitive Model of the Antecedents and Consequences of Satisfaction Decisions," J. Mark. Res., vol. 17(4), no. November, pp. 460-469, 1980.

[20] S. Çerri, "Exploring the Relationships among Service Quality, Satisfaction, Trust and Store Loyalty among Retail Customers," J. Compet., 2012, doi: 10.7441/joc.2012.04.02.

[21] M. J. Bitner, "Servicescapes: The impact of physical surroundings on customers and employees," J. Mark., vol. 56, no. 2, pp. 57-71, 1992.

[22] P. Richardson, A. K. Jain, and A. Dick, "The influence of store aesthetics on evaluation of private label brands," J. Prod. Brand Manag., 1996, doi: 10.1108/10610429610113384.

[23] J. Bloemer and K. de Ruyter, "On the relationship between store image, store satisfaction and store loyalty," Eur. J. Mark., 1998, doi: 10.1108/03090569810216118

[24] J. Semeijn, A. C. R. van Riel, and A. B. Ambrosini, "Consumer evaluations of store brands: Effects of store image and product attributes," J. Retail. Consum. Serv., vol. 11, no. 4, pp. 247258, 2004, doi: 10.1016/S0969-6989(03)00051-1.

[25] M. J. Bitner, "Evaluating Service Encounters: The Effects of Physical Surroundings and Employee Responses," J. Mark., 1990, doi: $10.2307 / 1251871$

[26] M. D. Hartline, J. G. Maxham, and D. O. McKee, “Corridors of influence in the dissemination of customer-oriented strategy to customer contact service employees," J. Mark., 2000, doi: 10.1509/jmkg.64.2.35.18001.

[27] J. N. Sheth and A. Parvatiyar, "The evolution of relationship marketing," Int. Bus. Rev., 1995, doi: 10.1016/09695931(95)00018-6.

[28] E. N. Berkowitz, J. Jacoby, and R. Chestnut, "Brand Loyalty: Measurement and Management," J. Mark. Res., 1978, doi: $10.2307 / 3150644$

[29] R. Bennett and S. Rundle-Thiele, "A comparison of attitudinal loyalty measurement approaches," J. Brand Manag., 2002, doi: 10.1057/palgrave.bm.2540069.

[30] D. D. Gremler and S. W. Brown, "Service loyalty: antecedents, components, and outcomes," in American Marketing Association. Conference Proceedings, 1998, vol. 9, p. 165.

[31] R. L. Oliver, "Whence consumer loyalty?," J. Mark., 1999, doi: $10.2307 / 1252099$

[32] A. C. Samli, T. L. Pohlen, and L. Jacobs, "Developments in retail logistics: Towards generating more consumer value," Journal of Marketing Channels. 2006, doi: 10.1300/J049v13n02_05.

[33] D. J. Bowersox, D. J. Closs, T. P. Stank, and S. B. Keller, "How Supply Chain Competency Leads to Business Success," Supply Chain Manag. Rev., 2000.

[34] S. Sandström, B. Edvardsson, P. Kristensson, and P. Magnusson, "Value in use through service experience," Manag. Serv. Qual. An Int. J., 2008, doi: $10.1108 / 09604520810859184$

[35] A. C. r. Van Riel, J. Semeijn, D. Ribbink, and Y. BomertPeters, "Waiting for service at the checkout: Negative emotional responses, store image and overall satisfaction," $J$. Serv. Manag., 2012, doi: 10.1108/09564231211226097.

[36] M. F. Najib and A. Sosianika, "Retail service quality, satisfaction, and trust: The key to shopper loyalty in the context of the Indonesian traditional market," Int. J. Electron. Mark. Retail., vol. 10, no. 4, 2019, doi: 10.1504/IJEMR.2019.104216.

[37] S. Cooper, D.R, and Schindler, Business Research Methods. 12th Edition. New York: McGraw-Hill/Irwin, 2010.

[38] R. L. Oliver, Behavioral perspective on the consumer. New York: McGraw-Hill/Irwin, 1997.

[39] F. Demirci Orel and A. Kara, "Supermarket self-checkout service quality, customer satisfaction, and loyalty: Empirical evidence from an emerging market," J. Retail. Consum. Serv., 2014, doi: 10.1016/j.jretconser.2013.07.002 
[40] D. Sirdeshmukh, J. Singh, and B. Sabol, "Consumer trust, value, and loyalty in relational exchanges," J. Mark., 2002, doi: 10.1509/jmkg.66.1.15.18449.

[41] E. Nijssen, J. Singh, D. Sirdeshmukh, and H. Holzmüeller, "Investigating industry context effects in consumer-firm relationships: Preliminary results from a dispositional approach," J. Acad. Mark. Sci., 2003, doi: $10.1177 / 0092070302238604$.

[42] N. . Malhotra, N.K., Baalbaki, I.B, and Bechmati, Marketing Research. UK: Peorson-Prantice Hall, 2003.
[43] J. . Nunnally, Psychometric Theory(2nd ed). 1978.

[44] J. F. Hair, W. C. Black, B. J. Babin, and R. E. Anderson, "Multivariate Data Analysis," Vectors. 2010, doi: 10.1016/j.ijpharm.2011.02.019.

[45] I. Ghozali, Model Persamaan Structural, Konsep dan Aplikasi Dengan program AMOS 22.0. (Structural Equation Model, Concept and Application with AMOS 22.0 program. Semarang: UNDIP, 2014 